$1-1-1989$

\title{
Privacy and the Regulation of the New Reproductive Technologies: A Decision-Making Approach
}

Antoinette M. Sedillo Lopez

University of New Mexico - School of Law

Follow this and additional works at: https://digitalrepository.unm.edu/law_facultyscholarship

Part of the Law and Gender Commons, and the Law and Race Commons

\section{Recommended Citation}

Antoinette M. Sedillo Lopez, Privacy and the Regulation of the New Reproductive Technologies: A Decision-Making Approach, 22 Family Law Quarterly 173 (1989).

Available at: https://digitalrepository.unm.edu/law_facultyscholarship/79

This Article is brought to you for free and open access by the UNM School of Law at UNM Digital Repository. It has been accepted for inclusion in Faculty Scholarship by an authorized administrator of UNM Digital Repository. For more information, please contact amywinter@unm.edu, Isloane@salud.unm.edu,sarahrk@unm.edu.

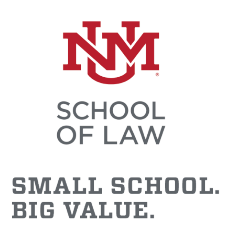

BIG VALUE. 


\section{Privacy and the Regulation of the New Reproductive Technologies: A Decision-Making Approach*}

\section{ANTOINETTE SEDILLO LOPEZ $\dagger$}

\section{Introduction}

Today scientists are able to harvest eggs from women,' fertilize them in vitro ${ }^{2}$ with sperm which has been separated so that it contains con-

\footnotetext{
*Copyright (C) 1988 Antoinette Sedillo Lopez. All rights reserved.

Author's Note: Footnotes that contain medical citations deviate from standard Blue Book form by including first initials of authors. This will facilitate research in this area.

†Ms. Sedillo Lopez, J.D. UCLA 1982, is an assistant professor of law at the University of New Mexico School of Law. She gratefully acknowledges the contributions of Professors Richard Delgado, Robert Schwartz and Lee Teitelbaum. She also thanks Dean Parnall for his support-personal, professional, and in the form of a summer research grant.
}

I. See L. Mettler, M. Seki, V. Baukloh \& K. Seem, Human Ovum Recovery via Operative Laparoscopy and In Vitro Fertilization, 38 FERT. \& STERIL. 30 (1982) (describes use of laparoscopy, which involves cutting through abdominal muscles and examining the interior with a special scope to recover oocytes for use in in vitro fertilization (IVF)); S. Lenze \& J. Lauritsen, Ultrasonically-Guided Percutaneous Aspiration of Human Follicles under Local Anesthesia: A New Method of Collecting Oocytes for In Vitro Fertilization, 38 FERT. \& STERIL. 673 (1982) (describes use of needle guided by ultrasound through abdomen to collect oocytes for in vitro fertilization. This method is less expensive and less traumatic than laparoscopy. It is usually called the "transvesical method"); M. Wikland, L. Nilsson, R. Hansson, L. Hamberger \& P. Janson, Collection of Human Oocytes by the Use of Sonography, 39 FERT. \& STERIL. 603 (1983) (describes further developments in the transvesical method introduced by Lenz and Lauritsen); $N$. Gleicher, J. Friberg, N. Fullan, R. V. Giglia, K. Mayden, T. Kesky \& I. Siegel, Egg Retrieval for In Vitro Fertilization by Sonographically Controlled Vaginal Culdocentesis, 2 LANCET 508 (July-Sept. 1983) (describes use of needle guided through vagina by ultrasound to collect oocytes for IVF; this is usually called the "transvaginal method"); M. Wikland, L. Enk \& L. Hamberger, Transvesical and Transvaginal Approaches for the Aspiration of Follicles by Use of Ultrasound in In Vitro Fertilization and Embryo 
centrations of male or female chromosomes, ${ }^{3}$ and implant the embryo ${ }^{4}$ in a surrogate (a woman who will carry the embryo to term). ${ }^{5}$ Scientists can discover information about the sex, gene structure, and some diseases of the resulting conceptus. Based on this information, a decision to terminate the pregnancy can be made. ${ }^{6}$ Future advances in technology ${ }^{7}$

Transfer, 442 Annals N.Y. ACad. Scı. 182 (M. Seppala \& R. G. Edwards eds. 1985) (discusses transvesical and transvaginal methods and compares them to other methods).

2. See generally Human Conception IN Vitro (R. G. Edwards \& J. M. Purdy eds. 1982); In Vitro Fertilization and Embryo Transfer, 442 ANNAls N.Y. ACAD. SCI. (M. Seppalla \& R. G. Edwards eds. 1985); L. Andrews, New Conceptions: A Consumer's Guide to the Newest infertility Treatments Including In Vitro Fertilization, Artificial Insemination and Surrogate Motherhood (1984).

3. Sex is determined at the time of fertilization in humans. A man's sperm contains either an $X$ chromosome or a $Y$ chromosome. A woman's egg contains only $X$ chromosomes. A sperm with a $\mathrm{Y}$ chromosome creates a male (XY) offspring. A female offspring is created when the sperm fertilizing the egg contains an $X$ chromosome (XX). Researchers have separated $X$ and $Y$ chromosomes by chemical treatment and centrifugation. The $X$ and $Y$ chromosomes are of slightly different weights. When sperm is centrifuged in a density gradient, the heavier sperm settle to the thicker and lower layers of the density gradient. If such separated sperm are used to fertilize the egg, presumably the chances of conceiving a child of the desired sex is increased. A process which concentrates $Y$ sperm to approximately 70 percent of the specimen was first used for cattle breeding. W. L. G. Quinlivan. K. Preciado, T. L. Long \& H. Sullivan, Separation of Human $X$ and $Y$ Spermatozoa hy Albumin Gradients and Sephadex Chromotography. 37 Fert. \& Steril. 104 (1982). The technique is now used in at least seven United States clinics and is advertised for sex selection and for male infertility. See generally A. Class \& R. Cruccaan, Getting Pregnant in the 1980's: New advances in INFERTILITY TREATMENT AND SEX SEl.ection (1982).

4. Scientists can discover such things as sex, gene structure, disease, etc., about the potential offspring by analyzing the fertilized egg at the blastocyst stage of development. See generally Biology of THE Blastocyst (R. J. Blandeau ed. 1971).

5. E.g., J. D. Biggers, In Vitro Fertilization and Embryo Transfer In Human Beings, 304 New Eng. J. Med. 336 (1981).

6. See Note, Sex Selection Abortion: A Constitutional Analysis of the Abortion Liberty and a Person's Right to Know, 56 IND. L.J. 281 (1981).

7. Over the past twenty years procreation or biological reproduction has become subject to increasingly intrusive medical technological intervention. See generally Wertz, What Birth Has Done for Doctors: A Historical View, 8 Women \& Health 7 (1983). For example, medical technology has made possible a wide range of alternative forms of conception, including artificial insemination. Wadlington, Artificial Conception: The Challenge for Family Law, 69 VA. L. Rev. 465, 468 (1983); in vitro fertilization, see note 2 supra; surrogate gestation, see Keane \& Breo, The Surrogate Mother (1981); Handel, Surrogate Parenting, In Vitro Insemination and Embryo Transplantation, 6 Whitrier L. Rev. 783 (1984); and perhaps, in the future, cloning, see Watson, Moving Toward the Clonal Man, 227 ATL. MONTHLY 50 (1971).

Other types of techniques connected with the new reproductive technology include in utero fetal therapy. See Robertson, The Right to Procreate and In Utero Fetal Therapy, 3 J. Legal MeD.-CHI. 333-66 (1982); fetal destruction, see, e.g., Kerenyi \& Chitkara, Selective Birth in Twin Pregnancy with Discordancy for Down's Syndrome, 304 New ENG. J. MED. 1525 (1981) (the doctors examined the twin fetuses and chose to abort the one with Down's Syndrome; the other remained in the womb to term); and fetal experimentation, cf. R. G. Edwards, Fertilization of Human Eggs In Vitro: Morals, Ethics and the Law, 49 Q. Rev. BIOLOGY 1i, 13-14 (1974). Another technique is embryofreezing: see A. Trounson \& L. Mohr, Human Pregnancy following Cryopreservation, Thawing and Transfer of an Eight-cell Embryo, 305 NATURE 707 (1983) (describes embryo freezing procedures). A review of the different techniques available by the development 
may bring the possibility of manipulating the egg, ${ }^{8}$ sperm, embryo, or fetus to alter characteristics of potential offspring even more dramatically. ${ }^{9}$

A number of critical issues must be confronted in society's decision to enter the brave new world of the new reproductive technology. ${ }^{10}$ The legal system, society's traditional mechanism for enforcing values and priorities, " will inevitably be called upon to grapple with the difficult issues which use of the new reproductive technology 12 will raise. ${ }^{13}$ Policymakers and lawmakers presently have two alternatives. One is to wait and decide whether to regulate each potential use of the new

of the new reproductive technology reveals that they can be categorized as follows: (1) those which are used as therapy for infertility; (2) those which require the participation of third parties; and (3) those involving manipulation of potential offspring. Each of these uses raises different concerns.

8. Research in manipulating eggs has been conducted in mice. R. D. Palmiter. G. Norstedt, R. E. Gelinas, R. E. Hammer \& R. L. Brinster, Methaliothionein-Human GHFusion Genes Stimulate Growth of Mice, 222 SCIENCE 809-14 (1983) (reported results of a study in which mouse genes and human genes were fused and then injected into fertilized mouse eggs. Mice which incorporated the genes (transgenic mice) grew larger than control mice). See also R. H. Lovell-Badge, Transgenic Animals: New Advances in the Field, 315 Nature 628 (1985) (review of research on gene manipulation in animals); R. D. Palmiter \& R. L. Brinster, Transgenic Mice, 41 Cell 343 (1985) (review of research involving gene manipulation in animals); R. L. Brinster \& R. D. Palmiter, Introduction of Genes into the Germ Line of Animals, 80 Harvey Lectures 1 (1984-85); and W. F. Anderson, Prospects for Human Gene Therapy, 226 ScIEnce 401 (1984) (discusses applying research in gene manipulation to humans).

9. Gene manipulation in animals has already been used for commercial purposes. See J. J. Rutledge, G. E. Siedel, Genetic Engineering and Animal Production, 57 J. ANIMAL Sci. 265 (Supp. 2 1983). And the new reproductive technology has been applied to manipulative uses in the context of selective abortions and genetic screening. See supra note 7 , infra notes $108-24$, and accompanying text.

10. For a discussion of some of these issues, see, e.g., Ethics Advisory Board, U.S. Dept. of Health, Education, \& Welfare, HEW Support of Research Involving Human In Vitro Fertilization and Embryo Transfer (1979); R. G. Edwards, Fertilization of Human Eggs In Vitro: Morals, Ethics, and the Law, 49 Q. REv. BıLogy 3 (1974).

11. See Teitelbaum, Family History and Family Law, 1985 Wis. L. Rev. 1135 (1985). Professor Teitelbaum discusses the history of governmental intervention in the family and demonstrates that governments and courts assumed substantial roles in childrearing, education, regulation of marriage, child custody, and spousal support during the nineteenth and early twentieth centuries.

12. This article uses the term reproductive technology to refer to any medical procedures which are used in childbirth. The new reproductive technology refers to medical procedures developed after the late 1970 s which manipulate the process of childbirth so that children who would otherwise not be born are born, or that characteristics of those children who would be born are altered.

13. There are proposed statutes concerning surrogate motherhood reprinted in $1982-$ 85 Hum. Reproduction \& L. ReP. (Legal Medical Studies) R71- 109 (1984). This is an example of commentators preparing for the legal problems raised by this particular method of utilizing the reproductive technology. See Note, Surrogate Motherhood: Contractual Issues and Remedies under Legislative Proposals, 23 WASHBURN L.J. 601 (1984), for an overview of legal issues and proposed solutions to the problems raised by the practice of surrogate motherhood. 
reproductive technology as it becomes available and as problems arise with its use. The other option is to anticipate potential developments and to formulate policies and laws that will guide researchers and medical professionals in their pursuits. For example, the government might prohibit procreative techniques that threaten the future gender and genetic composition of society. ${ }^{14}$

This article maps out the territory that must be explored in this very complex area and analyzes the implications of governmental regulation of the new reproductive technology. ${ }^{15}$ It suggests that the central issue for analysis is the extent to which authority to make decisions concerning reproductive potential should be allocated to individuals rather than to the government. The article describes approaches to allocating decision-making authority with respect to procreative issues. The first is a rights-based approach which emphasizes individual autonomy; this approach will not permit governmental regulation which interferes with personal autonomy in decision making, at least without good reason. The second approach accepts regulation which impinges on individual decision making for the public good.

The traditional two-tier substantive due process analysis incorporates both models by categorizing and balancing. ${ }^{16}$ This approach strengthens the perception that private and public spheres of human existence should be kept separate on the basis that the public sphere (i.e., work and politics) may be regulated, while the private sphere (i.e., home and family) is somehow beyond regulation. This idea has historically oppressed women by justifying their exclusion from the public sphere; its effect has been to perpetuate and legitimate a power imbalance in the private sphere. However, in the area of reproduction,

14. Presently the only use of reproductive technology which is regulated to some extent is the use of artificial insemination. See Unif. Parentage Act $\$ 5,9$ U.L.A. 593 (1980).

15. There is a tension in this article between advocating a new analysis and maintaining that the Court has already laid the groundwork for this analytical framework: the article thus predicts future analysis. In this article, I demonstrate that allocating decision-making authority and considering autonomy and societal benefit is something that the Court has already done in the area of substantive due process. However, the Court has not analyzed any questions concerning the new reproductive technology and has not set out a framework for considering procreational privacy questions in the way this article does. Professor Karst identified this tension as existing in most writing that addresses emerging legal doctrines. Karst, The Freedom of Intimate Association, 89 Y ALE L.J. 624, 626 (1980).

16. To illustrate, the first step in the traditional analysis is to consider whether regulation impinges on a fundamental right. This entails determining what rights are fundamental. The Court has held privacy to be such a right, but it has not yet decided whether it extends to decisions to use the various medical techniques available in aid of procreation. If the Court determines that a fundamental right is implicated, the Court looks to the state interests in the regulation to determine whether they are substantial. If so, the Court determines whether the regulation is the only practical means of furthering those interests. 
the rights-based notion of individual autonomy has empowered women. The article concludes that the problems associated with separate spheres can be minimized if the analysis focuses precisely on the application of the new reproductive technology and on the impact of individual autonomy on women and society.

This article maintains that that which is implicit in privacy analysis must become explicit. We must look closely at individual decisions to use procreative technology to see whether they implicate autonomy so strongly as to be deemed fundamental. After examining the effect of the regulation on autonomy in decision making, courts should examine the potential effect of decisions to use technology on others. Whenever possible, the courts should seek a solution that maximizes autonomy and concurrently prevents harm to others.

Three applications of the new reproductive technology will be analyzed: (1) treatment for infertility, (2) multiple-parent procreation, and (3) reproductive manipulation. After describing the medical technology available in each category, arguments for and against regulation are evaluated in light of their implications for autonomy and society. The article concludes that individuals should be free to choose the new reproductive technology as treatment for infertility unhindered by state interference; oversight and recordkeeping regulation adequately addresses societal needs in this instance. States should have the power to regulate multiple-parent procreation in order to protect innocent children and potential surrogates. Finally, manipulation of the reproductive process should be regulated only to the extent necessary to protect autonomy, prevent private gender discrimination, prevent the skewing of the gender and genetic pool, and prevent any one person or entity from controlling and upsetting the genetic development of future generations.

\section{Decision Making}

A principle issue in cases involving reproductive decisions is the allocation of decisional authority. For example, the crucial question in abortion cases is not whether an abortion will be performed, but whether, under the circumstances, the power to make that decision resides in the state or in the individual. ${ }^{17}$ The state may be regarded as a decision

17. That is, for example, in the case involving the decision to obtain an abortion, the court is not necessarily deciding whether an abortion will be performed but is deciding whether the power to decide whether an abortion will be performed will reside in the state or the pregnant woman. See Tribe, Forward: Toward a Model of Roles in the Due Process of Life and Law, 87 HARv. L. Rev. 1, 11 (1973). Sometimes the parental autonomy notion collides with the individual right to privacy, for example in those cases invalidating statutes requiring parental consent for minor child's abortion. See Belotti v. Baird, 443 U.S. 622 (1979). See also Planned Parenthood v. Danforth, 428 U.S. 52 (1976) (invalidating a statute requiring the husband's consent to an abortion). 
maker to the extent that regulation of access to the new reproductive techniques, as well as the use thereof, effectively limits individual choice.

The range of governmental regulation can be placed on a continuum. At one extreme, regulation in the form of prohibition may completely preempt individual decision making; a law prohibiting surrogate mother contracts would be such a regulation. An absolute ban obviously removes the freedom of individuals to choose to hire a woman to bear a child. It would also affect the surrogate's freedom to choose to bear a child and to choose to terminate her parental rights.

At the other extreme, the state might resolve not to regulate, thereby leaving individuals free to make their own decisions. Between these two extremes on the continuum falls regulation which limits, but does not wholly curtail, individual decision making. An example of such regulation is regulation which requires some form of minimum protection for the surrogate (perhaps including a minimum wage) and psychological evaluations of all parties to the surrogacy contract. Thus, the courts must consider the question of how to allocate decisionmaking authority and the extent to which autonomy may be affected by such regulation. ${ }^{18}$

\section{A. Approaches to Allocating Decision-Making Authority}

One approach to allocating decision-making authority is a rights-based autonomy theory. ${ }^{19}$ This view supports individual choice as the primary value which is protected by a zone of noninterference. ${ }^{20}$ The rights

18. Although these concepts have been analyzed as a question of market alienability or inalienability in a market-based approach to the allocation of resources, the primary concern in the marketplace is whether buyers and sellers can make unimpeded decisions in the marketplace or whether their ability to make decisions in the market will be impeded by other factors-in this case regulation. See Radin, Market Inalienability, $100 \mathrm{HARv}$. L. Rev. 1849 (1987). In this article, Professor Radin provides a theory which fills the gap between an economic view that views all things as freely exchangeable on an open market and a view that rejects markets entirely. She describes how the liberal view is pushed toward the economic view. She explores and finally rejects attempts based on economic analysis and liberal philosophical doctrines to justify particular distinctions between things that are and things that are not appropriately bought and sold in open markets. She proposes a pragmatic approach to market inalienability which relates to an ideal of human flourishing. She addresses the issue of full and partial commodification of sexuality and reproductive capacity and concludes that to the extent that we must not assimilate our conception of personhood to the market, prohibitions in trading certain aspects of personhood are justified.

19. Johnstone, The Right to Privacy: The Ethical Perspective, 29 Am. J. Juris. 73, 81 (1984).

20. Professor Teitelbaum describes this idea: "Rights theory, however, usually supposes a 'space' around the individual." He goes on to state that this "space" has a special claim not well accounted for in utilitarian approaches and which seems reflected in cases and commentary that emphasize family autonomy and family privacy. Teitelbaum, Moral Discourse and Family Law, 84 Mich. L. Rev. 430 (1985). 
stem from traditional liberal concepts ${ }^{21}$ which give priority to the individual and resist intrusions by the state. ${ }^{22}$

A contrasting view assigns priority to the common good, which requires determining the impact of particular rules or decisions on society in general. ${ }^{23}$ Cases which subordinate individual interests in autonomous decision making to the good of society reflect this value. ${ }^{24}$ Both individual and societal concerns are at stake in the controversy over reproductive technology. ${ }^{25}$

A problem with the rights-based approach is that it strengthens the conceptual distinction between the private and the public spheres of human existence. The private sphere of the home and family (the woman's domain) is considered to be somehow beyond regulation, whereas the public sphere of work and politics (the man's domain) is properly regulated. ${ }^{26}$ This distinction is problematic on several grounds. First, it may not be defensible on closer examination. ${ }^{27}$ Moreover, it has historically served in our legal system to justify barring women from participating in the world outside the private sphere. ${ }^{28}$ At the same

21. See, e.g., Kuflik, The Inalienability of Autonomy, 13 PнIL. \& Puв. Aff. 271, 29698 (1984).

22. This concept has also been described as "negative" liberty. See I. BerLIN, Two Concepts of Liberty, in ON LIBERTY 122 (1969). Using this analysis, decision-making authority should reside in the individual. This rights-based autonomy ideal presumes autonomous moral agency-it assumes that individuals are equal in having subjective will. See, e.g., Kuflik, The Inalienability of Autonomy, 13 PHIL. \& PUB. AfF. 271, 29698 (1984).

23. I. Berlin, ON Liberty (1969).

24. See notes $47-48$ and accompanying text.

25. On the one hand, a rights-based approach might maintain that the government should not intrude and that individuals should make decisions concerning their reproductive potential without interference from the government. Johnstone, The Right to Privacy: The Ethical Perspective, 29 Am. J. JuRIs. 73, 81 (1984). Autonomy would be the dominant value. Utilitarian notions would more readily accept state regulation if it appeared that society's goals would be furthered by such regulation. See generally 1 . BerLIN, ON LiBERTy (1969).

The rights-based autonomy approach to decision making poses problems for those who believe that as a society we should prohibit some decisions which could pose harm to self, others, and/or to society. Mill, On Liberty, in The CASE Against Mill 126 (1975); J. Feinberg, Harm to Self 75-79 (1986); Taylor, What's Wrong with Negative Liberty, in The Idea of Freedom 175 (A. Ryan ed. 1979); R. Nozick, Anarchy, State AND UTOPIA 331 (1974) (a free system would allow an individual to sell himself into slavery).

Conversely, utilitarianism is criticized as an infringement on freedom. Regan, Paternalism, Freedom, Identity and Commitment, in PATERnalism 113-17 (R. Sartorius ed. 1983). The next section will demonstrate that traditional constitutional analysis incorporates elements of both autonomy and of utilitarianism.

26. This notion became popular when industry effectively took production outside of the home and into the factory. See generally A. OAKely, Women's Work (1974).

27. Olsen, The Myth of State Intervention in the Family, $18 \mathrm{U}$. Mich. J.L. Reform 835 (1985); Teitelbaum, Family History and Family Law, 1985 WIs. L. Rev. 1135.

28. Bradwell v. State, 83 U.S. 130 (1872). 
time, it has fostered an unequal power balance within the family unit by deferring to the privacy of the family and declining to intervene. ${ }^{29}$

Yet, the treatment of birth control decisions and abortion decisions as beyond the scope of regulation has given women more control over their own reproduction, and thus has empowered them in this aspect of their lives. Although some have argued that privacy decisions primarily served men's needs and only incidentally served women's interests, ${ }^{30}$ a central aspect of power is control. The ability to control their reproduction has given women the opportunity to achieve additional gains in the workplace and in the political realm. Despite the risk of strengthening a harmful distinction, advocacy for the protection of women's choices does not pose the problems the distinction raises.

This article focuses on a central aspect of empowerment, i.e., the ability to choose. The authority to make decisions normally gives the decision maker control. The elimination of decision-making authority from a woman disempowers her. Important concerns are raised when one permits individual autonomy and declines to intervene, which creates a potential negative effect on women.

\section{B. Reproductive Choice in the Liberal Tradition}

The privacy cases seem to demonstrate the U.S. Supreme Court's special concern with autonomy as opposed to the needs of the state. Throughout the last century, the Court has protected autonomy in private family decision making at the expense of state interests. ${ }^{31}$ The Court has found that some types of reproductive decisions fall within the zone of privacy; these decisions should be protected by the U.S. Constitution as fundamental rights. ${ }^{32}$ For example, the decision to use

29. McGuire v. McGuire, 157 Neb. 226, 59 N.W.2d 336 (1953) (the court refused to order spousal support in an ongoing marriage). This is peculiarly a problem with treating the "family" as an entity with its own autonomy claims.

30. See A. Dworkin, Right-Wing Women 104-105 (1982).

31. In Pierce v. Society of Sisters, 268 U.S. 510 (1925), the Court considered an action brought to challenge the constitutionality of an Oregon statute requiring children to attend public schools. The Supreme Court affirmed a lower court ruling that the statute deprived the private schools of property and the parents of liberty without due process. $I d$. at 534-35. The Court stated that "the Act of 1922 unreasonably interferes with the liberty of parents and guardians to direct the upbringing and education of children under their control." Id. at 534-35.

Meyer v. State, 262 U.S. 390 (1923), concerned the constitutionality of a statute which prohibited the teaching of foreign languages to a child who had not finished the eighth grade. The Supreme Court held that parents have the right to decide how the child will be reared and taught.

See also Moore v. City of East Cleveland, 431 U.S. 494 (1977). The court stated: "This Court has long recognized that freedom of personal choice in matters of marriage and family life is one of the liberties protected by the Due Process Clause of the Fourteenth Amendment." Id. at 499 (quoting Cleveiand Board of Education v. LaFleur, 414 U.S. 632, 639-40 (1974)).

32. Roe v. Wade, 410 U.S. 113, 152 (1973) ("only personal rights that can be deemed fundamental . . . are included in this guarantee of personal privacy"); Skinner v. Oklahoma, 316 U.S. 535, 541 (1942) (procreation is a fundamental right). 
contraceptives $^{\mathbf{3 3}}$ and a woman's decision to obtain a first trimester abortion $^{34}$ have been protected from state regulation. ${ }^{35}$

The traditional two-tier method of constitutional analysis ${ }^{36}$ used to decide privacy issues does not currently offer much guidance in addressing issues raised by the new reproductive technology. With respect

33. In Griswold v. Connecticut, 381 U.S. 479 (1965), the Supreme Court struck down a Connecticut statute prohibiting the use of contraceptives and abetting of the use of contraceptives. The Court distinguished this regulation from economic regulation and found that this law "operates directly on an intimate relation of husband and wife and their physician's role in one aspect of that relation." $I d$. at 482 . Thus, the Court declined to defer to the legislative wisdom in the Lochner v. New York, 198 U.S. 45 (1905), tradition. Justice Douglas. writing the majority opinion. reviewed the Bill of Rights and determined that they describe a protection against governmental invasions "of the sanctity of a man's home and the privacies of life." Griswold at 484 (quoting Boyd v. United States, 116 U.S. 616, 630 (1886)).

The Court said that regulating the use of contraceptives seeks to achieve the goals (without stating what the goals of the legislation were) by means having a maximum destructive impact upon a relationship lying within the zone of privacy created by several fundamental guarantees found in the First, Third, Fourth, Fifth and Ninth Amendments. Thus, for the first time, the Court viewed a group of amendments as fashioning a zone of privacy upon which the state could not intrude. Griswold at 484.

In Eisenstadt v. Baird, 405 U.S. 438 (1972), the Court reaffirmed the right to privacy and extended it to protect unmarried individuals. The Court considered the conviction of Baird under a Massachusetts statute prohibiting the giving of contraceptives to unmarried persons. The Court overturned the conviction on equal protection grounds using very broad language: "If the right of privacy means anything, it is the right of the individual, married or single, to be free from unwarranted governmental intrusion into matters so fundamentally affecting a person as the decision whether to bear or beget a child." Id. at 453 (emphasis in original).

34. The landmark case, Roe v. Wade. 410 U.S. 113 (1973), seemed to extend the right to privacy, holding that the right was "broad enough to encompass a woman's decision whether or not to terminate her pregnancy." $/ d$. at 153 . The Court assumed that a woman has a fundamental right of privacy and balanced this privacy right with the state interests in protecting potential human life and in protecting the mother's health. $I d$. at 150 . The Court struck the balance by concluding that the woman's privacy interests were paramount in the first trimester, and the decision whether to abort could not be interfered with by the state. However, the state's interests became more compelling as the pregnancy progressed. Thus, reasonable regulation to protect the mother's health was permissible in the second trimester and regulation to protect the fetus would be permissible after viability. $I d$. at 63 . Later in the opinion, however, the Court stated: "it is not clear to us that the claim asserted by some amici that one has an unlimited right to do with one's body as one pleases bears a close relationship to the right of privacy previously articulated in the Court's decisions." Id . at 154. The Court may have been presaging issues concerning homosexuality. See Bowers v. Hardwick, 478 U.S. 186, $106 \mathrm{~S}$. Ct. 2841 (1986).

35. Even before the landmark cases of Griswold and Roe, Justice Douglas had found procreation to be a fundamental right. In Skinner v. Oklahoma, 316 U.S. 535 (1942), he wrote for the majority: "We are dealing here with legislation which involves one of the basic civil rights of man. Marriage and procreation are fundamental to the very existence and survival of the race. The power to sterilize, if exercised, may have subtle, farreaching and devastating effects...."Id. at 541 . See infra note 36 for a discussion of Skinner.

36. Using the current constitutional analytical framework, it is important to determine whether the decision to use the new reproductive techniques is encompassed by the right to privacy and, thus, is a fundamental right. The Court has considered procreation as a right only twice.

In 1927, the Court in Buck v. Bell, 274 U.S. 200 (1927), considered a case involving Carrie Buck, a woman committed to a mental institution. The Court considered the 
to whether the use of the new reproductive technology can be characterized as fundamental, the Court's categorization of activities as fundamental does not have a coherent conceptual framework; consequently, the nature of the right to privacy is unclear in important aspects. ${ }^{37}$

The usual argument made in favor of protecting an individual's right to use the new reproductive technology can be stated simply: a state's attempt to curtail an individual's quest for a child violates that individual's right to procreative autonomy. ${ }^{38}$ If the Constitution protects

interests of society and compared sterilization to compulsory vaccination and decided that the interests of society should prevail. The Court thus denied her due process and equal protection challenges. The Supreme Court stated: "it is better for all the world, if instead of waiting to execute degenerate offspring for crime, or to let them starve for their imbecility, society can prevent those who are manifestly unfit from continuing their kind. The principle that sustains compulsory vaccination is broad enough to cover cutting the Fallopian tubes." $/ d$. at 207.

Without overturning Buck v. Bell, the Court reached a different result in Skinner v. Oklahoma, 316 U.S. 535 (1942). Mr. Skinner was convicted of three felonies, and the state instituted proceedings under statutory authority to have him sterilized. The statute provided for sterilization of habitual criminals, who were convicted two or more times of certain felonies. The Court struck down the statute on equal protection grounds because the statute did not treat all felons equally. Although the Court looked to the disparate treatment in deciding the case on equal protection grounds, it stated: "We are dealing here with legislation which involves one of the basic civil rights of man. Marriage and procreation are fundamental to the very existence and survival of the race." $I d$. at 541. Thus, while not basing its decision on a right to procreate, the Court alluded to such a right.

The Court's traditional two-tier substantive due process analysis first requires courts to consider whether the prohibition burdens a fundamental right. Roe v. Wade, 410 U.S. 113,153 (1973). If not burdening a fundamental right, the state action justifying the regulation will not be rigorously reviewed but will be upheld if it is reasonably related to some legitimate state interest; see. e.g., San Antonio Indep. School Dist. v. Rodriguez, 411 U.S. 1 (1973) (education is not a fundamental right, thus traditional standard of review, which requires only that the state's system be shown to bear some rational relationship to legitimate state purposes, will be applied to a state's funding scheme). If the right implicated is found to be fundamental, the challenged state action will only be upheld if, upon a balancing of the various interests, the regulation is necessary to further a compelling state interest. Zablocki v. Redhail, 434 U.S. 374 (1978). See also Kramer v. Union Free School Dist., 395 U.S. 621, 627 (1969). Because the burden of justification is so high, most challenged legislation fails when it infringes on the exercise of a fundamental right. Thus, the Court's traditional analysis makes a broad distinction between fundamental rights and other rights; it generally permits individuals to exercise fundamental rights without government interference, unless the government has some compelling interest to further and tailors its legislation narrowly. Using the Court's analysis, the matter is set up as a conflict between the rights and interests of the individual in decision making and the needs and interests of the state in interfering with those decisions.

37. For example, the right to choose to abort a pregnancy is within the right to privacy; see Roe v. Wade, 410 U.S. 113 (1973). The right to choose sexual practice is not; see Bowers v. Hardwick, 478 U.S. 186 (1986). For a proposal that would explain the concept of privacy as a right to intimate association, see Karst, The Freedom of Intimate Association. 89 Y ALE L.J. 624 (1980).

38. Doe v. Kelley, 106 Mich. App. 169, 307 N.W.2d 438 (1981), cert. denied, 459 U.S. 1183 (1983) (Doe contended that baby broker statutes prohibiting the exchange of money or other valuable consideration infringes the constitutional right of privacy). See also, 
the decision not to procreate, it must protect the decision to procreate even if the means for such procreation are unusual. ${ }^{39}$ Although the argument is plausible, the Court has yet to determine the argument's validity. Does the privacy right shield all forms of procreation, ${ }^{40}$ including those requiring extraordinary medical technology?

A lower court, in striking down a Florida statute requiring parental and spousal consent to abortion, found that the concept of privacy protects the potential to procreate but not the opportunity to do so. ${ }^{41}$ In this case, the husband argued that a spousal consent requirement protected the spouse's privacy right to procreation (as established in Skinner), since the fetus being aborted was his. The court responded to this argument:

Although Skinner protected the individual's procreative rights, in practical terms these rights cannot be exercised alone. Hence, even without state interference, the right becomes meaningless in the absence of a willing partner. Skinner, therefore, did not guarantee the individual a procreative opportunity; it merely safeguarded his procreative potential from state infringement. ${ }^{42}$

This court's interpretation weakens the claim that the right to procreation protects decisions to use artificial forms of conception and gestation, since the potential to procreate and not the opportunity to procreate is protected. On the other hand, in the case of an individual who can have children only through artificial means, denial of those means affects his or her potential to procreate.

One justification for treating reproductive decisions as within the zone of privacy is that it would be almost impossible to enforce laws which interfere with these decisions because they are made in the privacy of the home. ${ }^{43}$ But the Supreme Court's recent decision up-

e.g.. Handel, Surrogate Parenting, In Vitro Insemination and Embryo Transplantation, 6 Whittier L. Rev. 783, 788 (1984); Robertson, Procreative Liberty and the Control of Conception, Pregnancy and Childbirth, 69 VA. L. REv. 405, 414-20 (1983).

39. See sources cited supra note 38.

40. In Carey v. Population Services Int'l, 431 U.S. 678 (1977), the Court considered a challenge to the constitutionality of a New York statute which prohibited the sale of contraceptives to minors. $I d$. at 681 . The Court struck down the statute, noting that the outer limits of the privacy right had not been marked, but that it included personal decisions concerning marriage, procreation, contraception, family relationships and childrearing and education. $I d$. at 684-85. The Court stated: "The decision whether or not to beget or bear a child is at the very heart of this cluster of constitutionally protected choices." Thus, the Court appeared to extend the right of privacy to include procreation. See also Paris Adult Theatre I v. Slaton, 413 U.S. 49, 65 (1973) ("privacy right encompasses and protects ... family, marriage, motherhood, procreation and childrearing" (emphasis added)).

41. Poe v. Gerstein, 517 F.2d 787 (5th Cir. 1975).

42. Id. at 789 .

43. Schneider, Moral Discourse and the Transformation of American Family Law, 83 Mich. L. Rev. 1803, 1837-38 (1985). Professor Schneider states that the inefficacy of enforcing family law is not surprising in that the very nature of family law suggests it 
holding state laws which punish sodomy casts doubt on this claim. ${ }^{44}$ And, in any case, the decision to use complex medical procedures or medical procedures requiring third-party participation is rarely made in the privacy of the home or even in the privacy of the confidential physician/patient relationship. For example, persons seeking to use surrogates must advertise for a surrogate and must use lawyers and other individuals to help with the arrangements. ${ }^{45}$ Moreover, it is possible to enforce regulations affecting collaborative conception and extraordinary medical procedures in connection with the state's power to regulate the medical profession.

Finally, even in the liberal tradition of protecting individual autonomy, ${ }^{46}$ the Court has found in exceptional circumstances that the needs of the state take precedence over individual privacy in decision making. Some cases stress the subordination of family privacy to the public interest. They have upheld laws requiring parents to have their children vaccinated so that the state could protect public health ${ }^{47}$ and upheld a state's conviction of parents for violating the child labor laws. ${ }^{48}$ With

should be inherently difficult to enforce. First, much of what family law seeks to enforce occurs in private. Second, the person against whom the law is enforced is often specially able to injure the person the law intervened to protect. Finally, in many family law situations, those whose conduct the law attempts to regulate are under psychological and emotional pressure which make them hard to coerce into compliance with the law's structure.

44. Bowers v. Hardwick, 478 U.S. 186 (1986).

45. Typically, persons seeking to use surrogates must advertise for a surrogate and must use lawyers and other individuals to help with the arrangements. Ince, Inside the Surrogate Industry, in TEST TUBE Women 99-116 (R. Arditti, R. D. Klein \& S. Minden eds. 1984); M. Keane \& D. Breo, The Surrogate Mother (1981) (attorney Noel Keane describes processing the paperwork for the surrogate mother's termination of parental rights and subsequent adoption in at least six cases).

46. There is probably no more right to use the new reproductive technology than there is a right to a heart transplant. See Annas, Allocating Artificial Hearts in the Year 2002: Minerva v. National Health Service, 3 AM. J.L. \& MED. 59 (1977). Nor does there appear to be a right to choose among medical procedures without state interference. See United States v. Rutherford, 442 U.S. 544 (1979). Cf. Maher v. Roe, 432 U.S. 464 (1977) (state may fund childbirth but not abortions); Beal v. Doe, 432 U.S. 438 (1977) (Court upheld state exclusion of welfare funding for nontherapeutic abortions). No Supreme Court case has determined whether the right to privacy extends to decisions to use the new reproductive technology. Justice Brennan was the only Justice who would have granted certiorari in Doe v. Kelley, 106 Mich. App. 169, 307 N.W.2d 438 (1981), cert. denied, 459 U.S. 1183 (1983) (fundamental interest to bear and beget children does not extend to protect contracts and compensation of surrogate mothers).

47. Jacobson v. Massachusetts, 197 U.S. 11 (1905). In Jacobson, the Supreme Court upheld a compulsory vaccination statute by saying: "the liberty secured by the Constitution of the United States does not import an absolute right in each person to be at all times, and in all circumstances, wholly freed from restraint. . . There are manifold restraints to which every person is necessarily subject for the common good." Id. at 26 (emphasis added).

48. Prince v. Massachusetts, 321 U.S. 158 (1944). Prince concerned the conviction of a child's guardian for permitting the child to sell religious magazines in violation of the Massachusetts child labor law. Id . at 159-60. Prince appealed her conviction on First 
respect to reproductive decisions, courts have upheld the state's power to sterilize individuals in those cases where the state's interests were believed to outweigh the individual's right to procreate. ${ }^{49}$

Similar state interests weigh against uses of the new reproductive technology. Decisions to acquire a child by using the new reproductive technology implicate the government's interests in regulating the medical profession and protecting the welfare of its citizens. For example, the state may claim an interest in seeing that potential surrogates and egg donors are protected physically and psychologically. ${ }^{50}$ Moreover, the state has an interest in protecting the children who might be separated from biological parents and ensuring that the children's best interests are protected. ${ }^{51}$ Finally, the state may assert an interest in the health of the gene pool. 52

Current fundamental rights analysis would require the Court to consider whether these interests are compelling or substantial. The Court's two-tier substantive due process analysis incorporates both a rightsbased and a utilitarian approach to allocating decision-making authority: the individual's fundamental rights will be protected, unless the state's interests or the potential harm to others indicates that some interference with a fundamental right is warranted. Although the current approach focuses on the relevant considerations, the analysis should focus precisely on the different issues raised by the different uses to which the new reproductive technology may be put.

\section{Proposed Analysis}

Because the Supreme Court, in its early decisions, used grand, expansive language about the choice to "bear and beget a child" and procreation lying at the heart of protected liberties, some commenta-

Amendment religious freedom grounds and a claim of parental autonomy. Id. at 164 . The Supreme Court upheld the conviction, stating that "[c]ustody, care and nurture of a child reside first in the parents, whose primary function and freedom include preparation for obligations the state can neither supply nor hinder. But the family itself is not beyond regulation in the public interest." Id. at 166 (emphasis added).

49. See Buck v. Bell, 274 U.S. 200 (1927); In re Cavitt, 182 Neb. 712, 157 N.W.2d 171 (1968).

50. For a psychiatrist's study of the psychological makeup of surrogates, see Parker, Surrogate Motherhood: The Interaction of Litigation, Legislation and Psychiatry, 5 INT'L J.L. \& Psychiatry 341 (1982); Parker, Making Better Babies in Surrogate MotherhoodThe Adult Psychological Ingredient, in Changing Conceptions: Children and Parents in the New Reproductive Age (in press).

51. The prevailing standard for courts deciding cases affecting children is the child's best interest. See, e.g., In re Seiferth, 309 N.Y. 80, 127 N.E.2d 820 (1955) (a fourteenyear-old's father refused treatment for his son's harelip; the court found it was in the best interests of the boy to refuse to order treatment).

52. See C. Grobstein, From Chance to Purpose (1981) (advocates a state-mandated program of genetic selection). 
tors focused on the nature of the right at stake, i.e., procreation, to conclude that government should have a very limited role in regulating the new reproductive technology. ${ }^{53}$ Others maintained that the protection extends only as far as the Court has taken it (if there) and should not be extended. ${ }^{54}$ In any event, it appears that most decisions to employ the new reproductive technology will raise a colorable constitutional claim.

Attention should now shift to the next set of issues: which applications of these technologies will be highly protected and which state interests will be permitted to override individual choice? The remainder of this article addresses these considerations. The next section reviews each type of technology by first describing it and then evaluating the extent to which regulation would be appropriate. In applying the proposed analysis, arguments will be evaluated in light of the effect of regulation on individual autonomy and on society.

\section{A. Treatment for Infertility}

One of the major uses of the new reproductive technology is the treatment for infertility. For example, in vitro fertilization is used to help a woman with blocked oviducts to conceive a child by fertilizing her egg outside the body with sperm. The conceptus is then implanted in her womb where it is brought to term. ${ }^{55}$

A law prohibiting infertility treatment would take away an individual's ability to choose whether to undergo medical procedures to bear a child. Some commentators have supported legislation prohibiting in vitro fertilization even in the "simple case" of a married infertile couple.

The most common objections to in vitro fertilization are (1) that this type of technology is "unnatural";56 (2) that it separates the procreative

53. See, e.g., Note, In Defense of Surrogate Parenting: A Critical Analysis of the Recent Kentucky Experience, 69 Kr. L.J. 877, 887 (1980-81).

54. See, e.g., Smith \& Iraola, Sexuality, Privacy, and the New Biology 67 MARQ. L. REv. 263 (1984).

55. An example of these procedures is the use of external fertilization and reimplantation which permits the possibility of giving women who are infertile because of nonfunctional, destroyed, or absent oviduct the opportunity to have a child. See, e.g., P. Steptoe \& R. Edwards, Implantation of the Human Embryo, LANCET 366 (Aug. 12, 1978). The authors are the doctors who helped Mrs. Brown give birth to Louise Brown in the much publicized case of the first "test tube baby" in 1978. See N.Y. Times, July 26, 1978, at 1, col. 5.; The Times (London) July 26, 1978, at 1.

56. See, e.g., Kass, Making Babies-The New Biology and the "Old" Morality, 26 Pub. InTEREST 318, 349 (1972). Kass writes:

Is there possibly some wisdom in that mystery of nature which joins the pleasure of sex, the communication of love, and the desire for children in the very activity by which we continue the chain of existence?

My point is simply this: There are more or iess human ways of bringing a chiid into the world. I am arguing that the laboratory production of human beings is no longer human procreation, that making babies in laboratories-even perfect babies-means a degradation of parenthood (author's emphasis). 
and the conjugal aspects of marriage, thus damaging the marital relationship $;{ }^{57}$ (3) that it brings us closer to a horrifying "brave new world" 58 scenario; (4) that it is risky for the offspring; (5) that it is expensive and the resources allocated to it would be better spent elsewhere; and, finally, (6) that adoption is a better solution to the problem of childlessness.

The first two objections limit individual choice with little benefit to society. If we were to object to modern medicine as "unnatural," we would object to many of the advances medicine has brought which have increased our life cycles and made many lives more pleasant. The implication of courts identifying and upholding only "natural" reproductive decisions is troubling, in part because there is little evidence that "unnatural" reproduction harms others. The courts would be seriously affecting individual autonomy without justification.

The objection to separating the procreative and conjugal aspects of marriage has been voiced by the Catholic $\mathrm{Church}^{59}$ and other religious groups. The objection is based on a concern about the effect on the family. It is true that the legal system often attempts to reinforce the family unit with its family law principles; however, there is no evidence that allowing infertile couples to conceive by use of the new reproductive technology will injure their marriage or family. And, absent evidence, it seems plausible that use of the new reproductive technology as treatment for infertility could strengthen the family unit by allowing more couples to have children. Indeed, the desire for a child must be strong for an infertile couple to undergo the expense and inconvenience of the procedures. ${ }^{60}$ Moreover, governmental enforcement of religious values is troublesome in its own right. ${ }^{61}$ There is, therefore, no real evidence supporting this objection and the problem of church/state entanglement with it.

57. Id.; P. RAmSey, Fabricated Man 38-39 (1970). ("We procreate new beings like ourselves in the midst of our love for one another, and in this there is a trace of the original mystery by which God created the world because of His love.")

58. A. Huxley, Brave New World (1932). In this tale, the family was abolished and reproduction was handled by the state in state hatcheries in which embryos were produced, monitored, and modified in an artificial environment. The modifications were deemed necessary for the production of a stable society.

59. Instruction on Respect for Human Life in Its Origin and on the Dignity of Procreation: Replies to Certain Questions of the Day. Pope John Paul II Vatican Doctrinal Statement on Human Reproduction, reproduced in N.Y. Times, March 11, 1987, at A14, col. 1. The Vatican believes that the sacrament of marriage does not give couples a right to a child but the right to perform the acts necessary to create a child. Separating the marital conjugal act from procreation is morally illicit and cannot be approved. Every child who comes into the world, no matter how conceived, however, is to be accepted as a living gift of God and must be brought up with love.

60. See, e.g., E. Pohlman, Psychology of Birth Planning 35-81 (1969) (discusses extent and sources of parents' desire for children); Kleiman, Anguished Search to Cure Infertility, Jan. 17, $1983 \$ 8$ (N.Y. Times Magazine).

61. Abington School Dist. v. Schempp, 374 U.S. 203 (1963). 
The third objection, i.e., that the new reproductive technology brings us closer to a scenario where children are manipulated and manufactured rather than born into families, impacts on techniques like genetic engineering ${ }^{62}$ or ectogenesis. ${ }^{63}$ However, this concern has little direct application to treatment for infertility. Children born through the use of the new reproductive technology as a treatment for infertility are born into families; other than the extraordinary medical procedures required to produce them, they are like children born into any other family.

The concern that the use of the new reproductive technology may alter the genetic pool of the human species is likewise misdirected in connection with the treatment for infertility. The argument presented is that permitting the infertile to conceive children will alter the natural genetic development of the human species, in that the infertiles' genes would otherwise disappear from the gene pool without the technology. However, infertility is normally not caused genetically but is more often caused by environmental factors, ${ }^{64}$ contraceptives, venereal diseases, and other medical processes. ${ }^{65}$ Thus, in the absence of external factors causing infertility, the infertiles' genes would naturally continue to appear in the gene pool.

The remaining three objections listed above have serious implications for individuals and society. Should the techniques fail, the risk of harm to potential offspring is a very serious consideration. Nonetheless, medical risks can be minimized by the supervision of peer review boards and agencies created by states and Congress. ${ }^{66}$ Oversight regulation and record-keeping requirements, rather than prohibition, would address the concern more directly.

As for the objection to the use of scarce resources, it does seem incongruous in an overpopulated world with widespread hunger to use

62. See infra text and notes at 108-24.

63. Ectogenesis is the theoretical possibility of nurturing an embryo through term completely outside a woman's womb. R. Francoer, Utopian Motherhood (1970). Some feminists are concerned about the consequences of such a possibility. G. COREA, The Mother Machine 250-59 (1985). A. Dworkin, Right-Wing Women 187-88 (1983).

64. S. Barlow, S. \& F. Sullivan, Reproductive Hazards of Industrial ChemICALS (1982).

65. G. Corea, The Mother Machine 144-65 (1985). Ms. Corea cites many medical sources pointing to the IUD, birth control pills, depo provera, DES, and venereal disease as causes of infertility.

66. A review of reported research reveals two abnormalities reported in in vitro fertilization: (1) a spontaneous abortion of a triploid fetus (a fetus with 69 chromosomes instead of the normal 46)-P. C. Steptoe, R. G. Edwards, \& J. M. Purdy, Clinical Aspects of Pregnancies Established with Cleaving Embryos, 87 BRIT. J. OrSTET. \& Gynecol. 757 (1980); and (2) a child born with transposition of the major vessels of the heart-C. Wood, A. Trounson, J. S. Leeton, P. M. Renore, W. A. W. Watlers, B. W. Buttery, J. C. Grimwade, J. C. Spensley \& V. Y. H. Yu, Clinical Features of Eight Pregnancies Resulting from In Vitro Fertilization and Embryo Transfer, 38 FERT. \& STERIL. 105 (1982). 
modern technology to create even more children. ${ }^{67}$ Adoption would certainly be a more efficient way to alleviate the problem of childlessness and world hunger. This important concern must be weighed against autonomy values. In our liberal tradition, in which procreation is a fundamental right closely protected by the Constitution, fertile couples are not required to forego having large families or adopting unwanted children. Poor women are not required to undergo sterilization or abortion to reduce the welfare rolls. ${ }^{68}$ These types of decisions are so firmly a part of our traditional notions of individual autonomy and freedom that only in a compelling situation should they be usurped by the government. ${ }^{69}$

Decisions to use reproductive technology in the simple case seem to be at the heart of the right to bear or beget children and, thus, would probably be protected as within the right to privacy. None of the state's interests described above are likely to be compelling enough to justify regulation prohibiting the decision to use the new reproductive technology. Oversight and record-keeping regulation would address the government's interests.

\section{B. Multiple-Parent Procreation}

In vitro fertilization and embryo transfer allow several individuals to participate in the creation of a family. ${ }^{70}$ The participants can include a sperm donor, an egg donor, and a woman who carries and nourishes an embryo or fetus to term. ${ }^{71}$ There are two typical versions of the multiple-parent procreation process. In the first, a couple contracts with a woman to be inseminated with the husband's sperm. She carries a child who is genetically related to her and to the sperm donor. Upon the child's birth, she terminates her parental rights. ${ }^{72}$ The husband

67. An article in a Mexican feminist magazine questioned the wisdom of spending vast sums on creating children with so many uncared for children in the world. Lamas, Las Feministas ante la Technologia Reproductiva, FEM. 31 (Marzo 1987). The author also questioned whether third world women and other poor women would be used as breeders for the wealthy.

68. Justice Stevens (concurring) in a recent abortion decision discussed some implications of allocating decision-making authority to the state. Thornburgh v. American College of Obstetricians and Gynecologists, 54 U.S.L.W. 4618, n.6 (U.S. June 10, 1986) ("[I]f federal judges must allow the State to make the abortion decision, presumably the State is free to decide that a woman may never abort, may sometimes abort, or, as in the People's Republic of China, must always abort if her family is too large.")

69. See supra notes $31-35$ and accompanying text.

70. See infra note 2.

71. See Comment, New Reproductive Technologies: The Legal Problem and a Solution, 49 TENN. L. REv. 303, 305 (1982) (reviews the legal status of children born through alternative means of reproduction and proposes modifications to the Uniform Parentage Act to provide for alternative statutory parentage for children born through these procedures).

72. Syrkowski v. Appleyard, 420 Mich. 367, 362 N.W.2d 211 (1985), is a case involving a surrogate mother contract and paternity issues. The court held that the state paternity act allows the court to determine paternity of the child born through the surrogate arrangement even though the mother was married. 
establishes paternity and his wife adopts the child. ${ }^{73}$ In the second typical situation, a woman is paid to be implanted with an already fertilized egg. ${ }^{74}$ She carries a child that, although not genetically related to her, develops in her womb and is nourished by her. Although some have questioned whether she is to be considered the "mother" of a child, at the time of birth she terminates her parental rights. The individuals who contracted with her take custody of the child and, if necessary, adopt it. ${ }^{75}$

Because a woman outside of the family unit is required, ${ }^{76}$ arrangements to use this type of technology are usually made contractually. ${ }^{77}$ At issue is whether a state's attempt to regulate such a contract between a couple ${ }^{78}$ and a woman violates the constitutional right to privacy. The usual argument is that since procreation is implicated, the state should not interfere. ${ }^{79}$

The argument in favor of permitting surrogate contracts without regulation rests on the motion of moral agency or "freedom to contract." 80 This theory, which emphasizes individual autonomy, supposes that the participants, including the women who would be surrogates, should

73. In re Adoption of Baby Girl L.J., 505 N.Y.S.2d 813 (Sup. Ct. 1986). The surrogate parent contract was given legal effect where all parties agreed that the child should go to the couple who contracted for her birth. But see In re Baby Girl, 9 FAM. L. REP. 2348 (BNA) (Ky. Cir. Ct. 1983) (surrogate mother does not have right to relinquish parental rights).

74. J. D. Biggers, In Vitro Fertilization and Embryo Transfer in Human Beings, 304 New Eng. J. Med. 336 (1981).

75. Note, Redefining Mother: A Legal Matrix for New Reproductive Technologies, 96 YALE L.J. 187 (1986) (proposes legal framework for delineating rights and duties of parties in surrogate arrangements).

76. Participation in the process is what distinguishes sperm donors and surrogate mothers. Sperm donors do not actively participate in the process, rather they simply supply genetic material and have no further connection in the creation of a child. See supra note 59. Also, artificial insemination is a well-established technique which was developed long before the techniques included in this article's definition of the new reproductive technology.

77. See N. Keane \& D. Breo, The Surrogate Mother (1981). Attorney Keane describes his role as a go-between for surrogates and couples desiring to contract with them for a child.

78. Although this article uses a couple in the example, there are, of course, other possibilities. A single man or woman may want to hire a surrogate to bear a child. This raises public policy implications beyond the scope of this article.

79. See the father's argument in In re Baby M, 13 FAM. L. REP. 2001, 2009 (BNA) (N.J. Sup. Ct. 1987). This case involved a surrogate's repudiation of a contract to bear a child. The court's analysis of the constitutional question was remarkably superficial.

80. See Comment, Baby-Sitting Consideration: Surrogate Mother's Right to 'Rent Her Womb" for a Fee, is Gonz. L. Rev. 539 (i982-633). See also, e.g., Muller v. Oregon, 208 U.S. 412, 421 (1908). ("It is undoubtedly true, as more than once declared by this court, that the general right to contract in relation to one's business is part of the liberty of the individual, protected by the Fourteenth Amendment to the Federal Constitution."). 
have the right to enter into binding contracts. ${ }^{81}$ Refusal to enforce surrogate contracts is paternalistic and is just as offensive as a regime which would not enforce a married woman's contracts. ${ }^{82}$ Multipleparent conception also avoids sterotypes about the role of women as mothers. Rather, it places an economic value on childbirth as if it were a service and permits women to make choices about their role as childbearers. ${ }^{83}$

However, despite notions of "freedom of contract," there are some types of contracts we decline to enforce. For example, to protect children, we do not endorse and, indeed, often prohibit agreements to sell children; ${ }^{84}$ to protect potential slaves we do not enforce contracts to sell oneself into slavery; ${ }^{85}$ and, to protect others, we do not enforce contracts to commit crimes. Although one can argue that refusing to

81. See Comment, supra note 80 at 556, 559. Havighurst, Limitations Upon Freedom of Contract, 1979 ARIZ. ST. L.J. 167, 183 (1979). The author states: "Every contract is not to be proscribed whenever judges, legislators, or administrators believe that its terms are unfair or unjust or in any degree opposed to the public interest. Just as there must be 'freedom for the thought we hate,' so there must also be, in a measure, freedom for the contract we hate."

82. Muller v. Oregon, 208 U.S. 412 (1908) (women are competent to enter into binding contracts and cannot be arbitrarily restricted by exertion of the police power of the state. It must be clear that there are issues of health, safety, and welfare at stake).

83. Landes \& Posner, The Economics of the Baby Shortage, 7 J. Legal Stud. 323, 337 (1978). In discussing adoption, the authors state that medical and legal services are only part of the costs of "producing and selling" a baby. The major other costs are: (1) opportunity costs of the natural mother's time; (2) any pain or other disability of the pregnancy and delivery; (3) any value she attaches to keeping the child rather than giving it up; and (4) the costs of search of the middleman in locating "supplier and demander." Id. at 337. The authors advocate taking interim steps, which can be reversed, to a legal full-fledged "baby" market. Id. at 337. Posner has recently stated that he "did not advocate a free market in babies." Posner, Mischaracterized Views, 69 Judicature 321 (1986).

84. Twenty-four states have enacted baby-selling statutes which prohibit the payment of money in exchange for a child. Katz, Surrogate Motherhood and the Baby Selling Laws, 20 Colum. J.L. \& Soc. Probs. 3, 8 (1986). See also, e.g., In re Willey v. Lawton, 9 Ill. App. 2d 344, 132 N.E.2d 34 (1956) (a natural mother with custody and her second husband agreed to adopt her children by her first husband and thereby relieve the defendant father of his support obligation provided $\$ 5,000$ was paid for the release. The court held that the contract was void as against public policy).

However, in Surrogate Parenting Assoc.'s. v. Commonwealth, 704 S.W.2d 209 (Ky. 1986), and In Re the Adoption of Baby Girl L.J., No. 358 (N.Y. Surr. Ct. 1986), the courts distinguished adoption under the baby-selling laws and surrogate contracts because the decision to sell the child is made before conception and the sperm donor is biologically related to the child. Why these factors make the practice not baby-selling is unclear from the case. When the decision is made is irrelevant as to whether a sale occurs. Also, the fact that one of the purchasers is related to the child does not obviate the fact that the surrogate mother is receiving money in exchange for relinquishing parental rights to her child. Childbirth should not be analogized to a "service" because a "product," the child, is transferred.

85. The Thirteenth Amendment assures that: "Neither slavery not involuntary servitude . . . shall exist within the United States . . "U.S. Const. Amend. XIII. A slave society degrades human life and thus injures us all. 
permit surrogate contracts is paternalistic, an underlying basis for this type of prohibition is justifiable protection of the child, ${ }^{86}$ an unquestioned concern of the state. Of course, it would have to be shown that children born of surrogacy arrangements were, in fact, harmed in some fashion.

An argument against multiple-parent procreation is that permitting surrogate contracts demeans motherhood by reducing it to a type of farming $; 87$ it relegates women who make these types of contracts to their biological function as reproducers, thus degrading and objectifying them as "mother machines." 88 Additionally, a surrogate contract is arguably an adhesion contract because there will generally be a disparity in incomes between those paying for the baby and the surrogate who carries the baby. Concern has been expressed as to the possible exploitation of third world women and other poor women, in that their economic situation will likely lead them to become breeders for the wealthy. ${ }^{89}$

Another argument for prohibiting surrogate mother contracts by regulation is that there is a critical bonding process that takes place between an infant and its mother. Enforcing surrogate mother contracts, thereby requiring surrogates to terminate their parental rights and relinquish all contact with their children, may damage both the surrogate and the child psychologically. The long-term consequences are unpredictable at this point in time because surrogacy is a relatively recent development. In addition to the possible harm to individuals affected by enforcement of the contract, society may be harmed in a much broader sense-the psychological harm to individuals is likely to have society-wide implications. Children and women damaged by the experience do not live in a vacuum. They interact with others; their psychological problems will affect those with whom they interact.

However, if there is potential for damage when the surrogate reneges on her contract, what if she does not want to renege on the contract but insists that the contract be enforced? Perhaps the psychological

86. "The sovereign has an interest in a minor child superior even to that of a parent; hence, there is a public policy against the custody of such a child become the subject of barter." $S$. Williston, A Treatise on the Law of Contracts $\$ 1744$ A (3d ed. 1961).

87. Dworkin, The Coming Genocide, in Right-Wing Women 174 (1983). The author argues that the farming model, like the brothel model of how women are socially controlled, exploits women. The author describes how the value and respect now granted to women in the farming model will be lost when reproductive capacity becomes an item of commerce.

88. See G. Corea, The Mother Machine 213-49 (1985); see also A. Dally, Inventing ioutherhoud: The Consequences of an ideal (1982); A. Rich, Of Womén Born: MotherhoOd as Experience and Institution (1976).

89. Lamas, Feministas ante la Technologia Reproductiva, 11 FEM. 31 (Marzo 1987). 
damage to the unwanted child and the corresponding damage to society will militate in favor of enforcement. Yet, the recent phenomenon of surrogates who regret the experience indicates that there may be psychological and emotional damage even if the surrogate does not renege on the contract. ${ }^{90}$

Apart from the concerns expressed above is the practical consideration that surrogacy may be unavoidable because of the infertiles' strong desire to have children. Since it is potentially impossible to curtail, the consideration of the interests of the children who are created looms large. One argument is that enforcing the contracts assures that the children born by use of these contracts will be cared for. This is illusory. If the person who pays for the child did not want the child for some reason, it would be impossible to force him to love and care for the child, just as it is impossible to make abusive and neglectful parents properly care for their children. Similarly, it is impossible to force the surrogate to care for a child she does not want if those who contracted with her change their minds.

All of the above considerations ${ }^{91}$ should be examined in considering the implications of regulating multiple-parent procreation. In evaluating the arguments and the effect on the individual and society, two considerations emerge. The first is protecting the interests of the children. Children cannot speak for themselves or represent their own interests. We, thus, have an obligation to protect them. ${ }^{92}$ The question should not be whether the contracting parties have a fundamental right to decide to enter into these types of agreements, but the extent to which legislatures can legislate to protect the children. ${ }^{93}$ Second, the legislature should be able to protect potential surrogates who might be harmed or exploited. Therefore, the focus of regulation must be on the extent to which the state can regulate in order to protect children and surrogates.

90. Mothers Urge Ban on Surrogacy as Form of Slavery, N.Y. Times, Sept. I, 1987, $\$ \mathrm{~A}$ at 13 , col. 1 .

91. Do children have the right to know who their biological parents are? Many adopted persons now insist that they have the right to information about their biological parents. Arguably, children born through the use of the new reproductive technology should have similar rights. See generally J. Triseliotis, In Search of Origins: The Experiences OF ADOPTED PEOPLE (1973); Klibanoff, Genealogical Information in Adoption: The Adoptee's Quest and the Law, II FAM. L.Q. 185 (1977) (the rights to privacy of the adopted child and the natural parents must be balanced).

92. Annas \& Elias, In Vitro Fertilization and Embryo Transfer: Medicolegal Aspects of a New Technique to Create a Family, 17 FAM. L.Q. 199, 219 (1983).

93. See, e.g., Krause, Artificial Conception: Legislative Approaches, 19 Fam. L.Q. 185 (1985) (proposes that commercial surrogate motherhood should be made illegal with criminal sanctions on intermediaries. The primary concern of any legislation should be to protect the children resulting from surrogate activities). 


\section{Reproductive Manipulation}

The new reproductive technology can also be used to manipulate or change the characteristics of potential children and future generations. For example, genetic screening can influence the decision to have children by giving parents information about the characteristics their children are likely to have. ${ }^{94}$ Amniocentesis provides information about the unborn and, coupled with selective abortions, permits the termination of pregnancies based on the information obtained about the fetus. ${ }^{95}$ Finally, the fetus can be altered during pregnancy using in utero fetal therapy. ${ }^{96}$ The future may bring chromosome or gene substitution and modification, ${ }^{97}$ parthenogenesis, ${ }^{98}$ and perhaps cloning. ${ }^{99}$ These possibilities raise the same question noted earlier: who should make the decisions required when the new reproductive technology is used to manipulate the reproductive process and affect potential children and future generations?

Many states passed compulsory, extensive sterilization laws between 1911 and 1930. ${ }^{101}$ However, those laws have come into question. ${ }^{102}$ Today individuals, in consultation with their physicians, decide whether to employ the technology that is presently available and whether they

94. Genetic screening may be defined as a search in a population for persons possessing certain genotypes that: (1) are already associated with disease or predisposed to disease; (2) may lead to disease in their descendants; or (3) produce other variations not known to be associated with disease. Committee for the Study of Inborn Errors of Metabolism, Genetic Screening, National Academy of Sciences 9 (1975).

95. Delgado \& Keyes, Parental Preferences and Selective Abortion: A Commentary on Roe v. Wade, Doe v. Bolton, and the Shape of Things to Come, 1974 WASH. U.L.Q. 203; Note, Sex Selection Abortion: A Constitutional Analysis of the Abortion Liberty and a Person's Right to Know, 56 IND. L.J. 281 (1981).

96. See, e.g., Harrison, Golbus \& Filly, Management of the Fetus with a Correctable Congenital Defect, 246 J.A.M.A. 774, 775 (1981). In this case a defect was corrected.

97. See, e.g., Cohen, Gene Manipulation, 294 New Eng. J. Med. 883-88 (1976); C. Grobstein, From Chance to Purpose: An Appraisal of External human FerTiLization 54-58, 123-25 (1981); Anderson, Gene Therapy, 246 J.A.M.A. 2737, 2739 (1981).

98. Daniloff, Life Without Fathers? Wash. Post, Feb. 3, 1980, at C1, col. 2. (scientists claim to have produced rats from unfertilized ovae); L. KARP, GENETIC ENGINEERING: Threat or Promise? 186-88 (1976) (explains parthenogenesis as the development of an unfertilized egg into an embryo-fetus-individual).

99. G. Corea, The Mother Machine (1985). For a bibliographic index of the development of genetic engineering as followed by the media, see Smith, The Genetic Engineering Revolution: A New Century Reality (published by How. L.J. (1986)).

100. The conflict in decision-making authority raised when parents or guardians seek to make these decisions is beyond the scope of this article. See Note, In re Guardianship of Eberhardy: The Sterilization of the Mentally Retarded, 1982 WIS. L. REv. 1199 (1982).

101. See K. Ludmerer, Genetics and American Society: A Historical ApPRaISAl (1972); Beckwith, Social and Political Uses of Genetics in the United States; Past and Present, 265 Annals N.Y. ACAD. SCI. 46-58 (1976) (study of the early eugenics movement in the United States).

102. Skinner v. Oklahoma, 316 U.S. 535 (1942); Relf v. Weinberger, 372 F. Supp. 1196 (D.D.C. 1974). 
wish to do anything about the results. ${ }^{103}$ However, as the reproductive technology becomes more sophisticated, states may become interested in the potential for affecting its future citizens. States may be interested in having mandatory genetic screening programs, mandatory amniocentesis, or compulsory abortions to prevent the birth of babies with severe abnormalities (thereby reducing health care costs). ${ }^{104}$ The state might want to improve the gene pool, ${ }^{105}$ or perhaps the state may be interested in eliminating "undesirables" from society. ${ }^{106}$ Of course, there are the even more chilling possibilities that the state might want to encourage social stability and eliminate potential dissenters from its midst.

Obviously, techniques to manipulate the reproductive process entail an intrusive invasion of the mother's body and expose the mother and her unborn child to possible risk. If the techniques fail, the mother and her child are the parties who will suffer the most. Thus, the effect on the individual is great; the weight is in favor of individual decisionmaking authority.

Permitting individuals to make choices concerning the characteristics of their potential offspring will further a pluralistic society in that individuals will probably choose to have offspring that resemble themselves. On the other hand, permitting individuals to make choices involving gender and genetic composition might result in skewing the population. For example, many couples prefer first-born boys. ${ }^{107}$ Permitting individuals to make these types of decisions might, indeed, have a negative effect on society. ${ }^{108}$ Thus, the state might want to

103. Currently pregnant couples can use amniocentesis to discover whether the child the woman is carrying has certain types of defects. If so, the parents can decide whether to abort it. See generally Carlton, Perfectibility and the Neonate: Providers, in THE Custom-Made Child (H. Holmes, B. Hoskins, \& B. Gross eds.). See also Virshup, The Promise and the Peril of Genetic Testing: Perfect People? N.Y. Magazine, July 27, 1987, at 26.

104. Virshup, The Promise and the Peril of Genetic Testing: Perfect People? N.Y. Magazine, July 27, 1987 , at 26.

105. See G. Smith, Genetics, Ethics and THE LAw (1981) (the author advocates a state mandated program of active eugenics on the grounds that it is in the interests of society to improve the gene pool; generally, the author sees no drawback to prohibiting the passing of "bad"' genes).

106. In Buck v. Bell, 274 U.S. 200 (1927), the Supreme Court upheld the constitutionality of a Virginia statute providing for the sexual sterilization of inmates of institutions supported by the state who are found to be afflicted with a hereditary form of insanity or imbecility. The case has never been overruled; see Strickberger. Genetics 151-52 (2d ed. 1976), for an overview of eugenic sterilization of this country.

107. E.g., C. RICE, BEYONd ABortion 98 (1979) (women were more likely to abort if they were told that the sex of their child was female); Cutright, Belt \& Scangoni, Gender Preferences, Sex Predetermination, and Family Size in the United States, 21 Soc. Biology 243 (1974). But see L. Karp, Genetic Engineering: Threat or PromISE? 158 (1976) (suggests that any imbalance in the sex ratio would be short lived).

108. Scientists predict some of the following consequences of a society with a higher ratio of males in the population: a decrease in population growth, increased crime and wars, increased male homosexuality, increased polyandry, and finally, possible increased 
prevent individuals from making decisions that could harm society. The state might want to prohibit potentially harmful decisions, such as the decision to abort a child solely because of its sex or because of some other benign characteristic, such as eye color, skin pigmentation, ${ }^{109}$ etc. The state, for example, may want to prohibit sex-selection abortions on the grounds that this is an inappropriate, private gender-based discrimination which would result in an unnatural balance of the sexes in our society. ${ }^{110}$

However, if the state interferes with individual decision making by regulation prohibiting, for example, sex selection abortion, the concern is raised that it could also usurp these kinds of decisions and actually make decisions about the characteristics of potential children."11 Yet, the fact that the state is permitted to prohibit some kinds of decisions which might have a harmful effect on society does not automatically give it the power to make decisions about the characteristics of our children. Our important interests in autonomy and pluralism indicate that the state should not have that power.

Respect for privacy and autonomy protects individuals from many forms of governmental intrusion when they make procreative choices about the characteristics of their future children. The state, thus, should only regulate to prevent private gender-based discrimination, to prevent genetic or gender skewing of the population, and to prevent any one person or entity, including the government, from being able to control the natural genetic development of the human species.

\section{Conclusion}

Whether state control of decisions to use reproductive technology will be construed as within the zone of privacy, and, thus, a matter of individual autonomy, or a matter of grave social concern will depend

occurrence of first-child personality traits in males and later-child personality traits in females. Largey, Reproductive Technologies: Sex Selection, in 4 Encrclopedia of Bioethics 1439, 1443, cited in Note, Sex Selection Abortion: A Constitutional Analysis of the Abortion Liberty and a Person's Right to Know, 56 IND. L.J. 281,287 n.23 (1981).

109. Skin cells indicative of pigmentation (melanocytes in the epidermis) begin to appear at about the fourteenth week of gestation. See Sagebiel \& Odland, Ultrastructural Identification of Melancytes in Early Human Embryos, in Pigmentation: Its Genesis ANd Biologic Control 43, 44 (V. Riley ed. 1972), cited in Delgado \& Keyes. Parental Preferences and Selective Abortion: A Commentary on Roe v. Wade, Doe v. Bolton, and the Shape of Things to Come, 1974 WASH. U.L.Q. 203 n.58.

110. One way for the state to achieve this goal would be to prohibit the use of medical testing for the sole purpose of identifying fetal sex. Another way would be to require doctors to determine the reason for the abortion and to prohibit the abortion if the sole reason for the abortion is the sex of the fetus. The easiest way might be to withhold information about the sex of the fetus on the grounds that it is irrelevant. Sex-linked diseases may be an exception.

111. See generally A. Huxley, Brave New World (1932); G. OrWell, 1984 (1946). 
on the purpose or use to which technology is to be put. This article began by asking which applications of the new reproductive technology will be highly protected by the doctrine of privacy and which will be less so. It also asked which state interests justify overriding individual choice. It determined that the privacy doctrine treats the question as a conflict between individual autonomy and government interests in regulation. It found that treating these cases as conflicts between the autonomy of the individual and the needs of government strengthens the notion that the private and public spheres should be kept separate.

The notion of separate spheres has historically oppressed women. However, in the area of reproduction, the rights-based notion of individual autonomy has empowered women by permitting them to control their reproductive capacities. The article concluded that the problems associated with separate spheres can be minimized if the analysis focuses precisely on the application of the new reproductive technology and is sensitive to the effect of individual choices on women and society.

Applying the analysis proposed, the article found that the autonomy value outweighs concerns raised by the use of technology as treatment for infertility so that only minimal oversight and record-keeping regulation is warranted. With respect to the use of the new reproductive technology in multiple-parent procreation, it found that the possible exploitation of women and the potential harm to children are interests which can outweigh the interests of autonomy; regulation is thus justified in order to prevent exploitation and to protect children. Finally, in considering the regulation of the use of the new reproductive technology to manipulate characteristics of potential children, the article determined that the interests of preventing private gender discrimination and skewing of the gender and genetic composition of humanity permit regulation to further those interests but do not permit regulation which attempts to usurp decision-making authority so that the government would make substantive decisions about the gender and genetic composition of humanity. 
